\title{
FLIPPED CLASSROOM FOR TEACHING DIGESTIVE SYSTEM TO HIGH SCHOOL STUDENTS: PERFORMANCE, PERCEPTION AND INQUIRY COMPETENCE LEVEL
}

\author{
Roberto Reinoso Tapia (D), Miguel Ángel Collazos Martínez (D), \\ María del Carmen Martínez Martínez iD, Jaime Delgado Iglesias ii \\ University of Valladolid (Spain) \\ roberto.reinoso@wva.es,mcollazosma@gmail.com,mcarmen.martinez@uva.es,jaime.delgado.iglesias@uva.es
}

Received October 2020

Accepted December 2020

\section{Abstract}

This article presents an educational experience with 30 high school students based on the flipped classroom methodology and inquiry-based learning on aspects related to the pathophysiology of the digestive system during the $2017 / 2018$ academic year. The main goal of this study was to investigate the effectiveness and acceptability of the flipped classroom approach at this educational level. This study was also used to assess the level of inquiry competence that high school students present when they have to carry out a research project and the main difficulties encountered in carrying it out. The results of the study show that the experience was clearly positive, since there was not only a significant improvement in student learning but also greater autonomy for students to work with the content, prepare for classes and actively participate in the tasks or practical activities that take place in the classroom, demonstrating its applicability in high school classrooms. The results also indicate that the students perceived advantages in their learning after experiencing the flipped classroom pedagogical model. Most of the students presented serious difficulties in carrying out their research work, probably due to a lack of experience when facing each of the stages that make up the process of inquiry.

Keywords - Flipped classroom, Active learning, Inquiry, Digestive system, High school students.

\section{To cite this article:}

Reinoso Tapia, R., Collazos Martínez, M.A., Martínez Martínez, M. del C., \& Delgado Iglesias, J. (2021). Flipped classroom for teaching digestive system to high school students: Performance, perception and inquiry competence level. Journal of Technology and Science Education, 11(1), 194-209. https://doi.org/10.3926/jotse.1122

\section{Introduction}

One of the most important challenges facing our education system today is the move from traditional teaching, focused on the direct transmission of information from the teacher, to a teaching that encourages discussion spaces and activities focused on the student, where multidirectional interaction between the teacher and the students is prioritised, and between the students themselves. The inverted learning model or "flipped classroom" seeks to reverse the traditional teaching roles and spaces, so that the conceptual content typically taught by the teacher in the classroom is considered by the student prior 
to the face-to-face sessions, leaving time for the class to carry out other types of more practical activities. One possibility to take advantage of the teaching design is to apply inquiry as a working method. In fact, different recommendations have been issued by international organizations and educational authorities to promote learning in the classroom that encourages critical thinking and active methodologies in which student participates and applies scientific reasoning. For this reason, it seems appropriate to use inquiry in combination with the flipped classroom. In this way, it is possible to mobilise direct teaching towards learning spaces that allow student learning to be maximised and time in the classroom that is free to implement active methodologies, as well as follow-up and timely support for the needs of each student. The "flipped classroom" methodology assumes support for inquiry as a teaching strategy, meaning that students use a more autonomous approach to access knowledge and, at the same time, there is more direct monitoring of their learning by teachers. This teaching model has been widely tested in university contexts; studies assessing the suitability of this methodology for pre-university educational levels, however, are lacking, even though the initial development of this methodology also took place in high schools and colleges. High school students find it exceedingly difficult to think critically and are not able to apply the scientific method to solve certain problems, presenting serious difficulties, for example, in formulating hypotheses and developing a work plan that allows them to contrast these approaches. Most of these students are used to simply memorising the content taught by the teacher and need help in setting up an investigation. The traditional teaching-learning methodology, in which the students are mere recipients, is still deeply rooted in our educational system; this seriously harms these students, who, upon arrival at a university, must confront a barrier that they do not know how to overcome.

In this research study, an educational experience is presented with students of 1st Spanish Baccalaureate, based on the flipped classroom methodology and the inquiry as a combined method of working in the classroom, on aspects related to the anatomy and pathophysiology of the digestive system. The experience was developed with the following objectives:

- Evaluate whether the "flipped classroom" methodology can be applied in the Baccalaureate.

- Assess the students' perceptions of the methodology.

- Identify the level of inquiry competence and the main difficulties that students experience when they have to carry out research or inquiry work.

\section{Theoretical Framework}

\subsection{The Inverted Methodology or Flipped Classroom}

The methodological paradigm of a reverse classroom or "flipped classroom", also called "flipped teaching" or "flipped learning", is based on a series of constructivism principles where students take responsibility for their own learning process (Bergmann \& Sams, 2012). This new pedagogical approach seeks to promote a change in the traditional teaching-learning methodology, and where the transmission of information is carried out outside the classroom, allowing the student to access such content when they want to do so, and as many times as necessary during pre-class preparation (González-Gómez, Jeong, Airado-Rodríguez \& Cañada-Cañada, 2016; Jeong, González-Gómez \& Cañada-Cañada, 2016). This means that students can spend their time in the classroom carrying out other activities that involve them in their own learning process, such as practical cases, active learning exercises, problem solving, formative evaluation, discussion activities or projects in which they work with what they have already learned and assimilated through preparatory self-study (Prieto, 2017).

Another of the great advantages of this methodology is that students can organise their time more effectively and set their own learning pace (Davies, Dean \& Ball, 2013; Tourón \& Santiago, 2015). The inverted learning model means that students can play a greater role in, and take greater responsibility for, their own learning process, and are able to move through the curriculum at the speed that their capacity and level of mastery allows (O'Flaherty \& Phillips, 2015). Another feature of this model, which it shares with the just-in-time teaching methodology (Novak, Gavrin, Christian \& Patterson, 1999), is the opportunity for the teacher to receive feedback from students before explaining instructional 
content in class. This communication makes it easier for the teacher to adapt their teaching to the difficulties of their students, and to adapt their explanations and exercises according to the most common queries of their students (Dávila, Borrachero, Cañada, Martínez \& Sánchez-Martín, 2015). Due to their previous study, students are much better prepared to actively participate in the class by answering questions or solving the problems raised (Prieto, 2017). It is therefore not surprising that there are more and more studies demonstrating a high degree of satisfaction in students who work and learn with this new teaching methodology (González-Gómez et al., 2017; Gopalan, 2019; Jeong et al., 2018; Long, Logan \& Waugh, 2016; Romero-García, Buzón-García \& Touron, 2018; Sánchez-Rivas et al., 2019). However, most of these studies have been carried out in university contexts, where it seems clear that the inverted model fits perfectly. Although there are more and more studies, there are still few that evaluate the suitability of this methodology for pre-university educational levels. In the case of the Spanish education system, the curriculum does not usually include a defined time in the annual calendar for work outside the classroom. It is true that in pre-university classrooms, dialogue between teachers and students within the framework of active learning is common, and it is also common for students to have tasks to do at home related to the content developed in class, but these cannot necessarily be considered linked to a flipped classroom context because this is something more than that and implies specific intentionality and planning.

\subsection{Inquiry-based learning}

The inclusion of the inquiry as an object of active learning is strongly recommended in many of the current strategies for the teaching of science, since it gives students the opportunity to participate in a real investigation, and, so practice the procedural skills of science, in addition to developing critical thinking and the ability to solve problems (Martínez-Chico, Jiménez-Liso \& López-Gay, 2014; Pimvichai, Yuenyong \& Buaraphan, 2019; Rosa, 2019; Rusmansyah, Yuanita, Ibrahim, Isnawati \& Prahani, 2019). Bevins and Price (2016) suggest that inquiry is the best method for teaching science; promoting research skills in students and helping them internalise new knowledge in the search for answers to scientific questions. This type of methodology has been widely used in recent years to offer numerous benefits for student learning, and to achieve a greater degree of student involvement and motivation (Couso, Jiménez, LópezRuiz, Mans, Rodríguez, Rodríguez et al., 2011; Furtak, Seidel, Iverson \& Briggs, 2012; Jeong, GonzálezGómez, Cañada-Cañada, Gallego-Picó \& Bravo, 2019; Lazonder \& Harmsen, 2016; Lederman, Lederman \& Antink, 2013; Minner et al., 2010; National Research Council [NRC], 2012; Ofsted, 2011; Osborne, 2011; Sshana \& Abulibdeh, 2020). However, it is also necessary to highlight that in order for this process to generate significant benefits for students, the teacher must plan, articulate and guide the student inquiry, since, as has been widely demonstrated, the best learning results are obtained when a teacher acquires the role of counsellor and activator of the student's ability to think and reason (Alfieri, Brooks, Aldrich \& Tenenbaum, 2011; Furtak et al., 2012; Lazonder \& Harmsen, 2016; Minner, Levy \& Century, 2010). One of the most common strategies in this regard is the use of cooperative inquiry, where students explore scientific questions via different guided inquiry strategies while collaborating in small groups in which they share and discuss information through mutual interactions (Ucan \& Webb, 2015).

In the baccalaureate educational stage (16-18 years) it is common to propose the performance of open and autonomous research work with students, but the practical works usually addressed in classrooms involve a low level of inquiry (Fay, Grove, Towns \& Bretz, 2007; Tamir \& Garcia, 1992). According to Caamaño (2012, proper translation):

Practical research papers should be activities designed to give students the opportunity to work in a way that has similarities with that used by scientists in problem solving, to familiarise themselves with the scientific work and to acquire a procedural understanding of science, by using the skills and procedures of scientific inquiry in a school setting. (page 84)

Even so, it is common for students to have serious difficulties when carrying out the processes that are part of the inquiry work, such as the formulation of a hypotheses and inquiry questions (Ferrés-Gurt, 2017; Furman, Barreto \& Sanmartí, 2013; Oliveras, Márquez \& Sanmartí, 2012), the identification of 
variables and the design of experiments (Crujeiras \& Jiménez, 2015; Cruz-Guzmán, García-Carmona \& Criado, 2017; D’Costa \& Schlueter, 2013; Ferrés, Marbà \& Sanmartí, 2015; González \& Crujeiras, 2016), data analysis and the elaboration of argued conclusions (Sanmartí \& Oliveras, 2011; Vílchez \& Bravo, 2015), and so on. These difficulties probably have their origin, as some authors point out, in the lack of preparation of students for carrying out each of these stages, since, in most cases, this is the first time that high school students face real research work (Ferrés et al., 2015). This reason, together with the greater degree of autonomy required by the inquiry work, in which students must make decisions related to the design and planning of the research to be carried out, reinforces the idea that this competence should be taught in the first courses of obligatory secondary education, and should be developed gradually, with guidance, so that students work on various activities with different levels of autonomy (Fernández-López, 2011).

\section{Methods}

\subsection{Participants}

The participants $(\mathrm{n}=30)$ were first-year Baccalaureate students who were studying the Applied Anatomy course (an elective of the 1st Baccalaureate according to the basic curriculum of the ESO and the Baccalaureate by Royal Decree 1105/2014, of 26 December) at a semi-private school in Valladolid (Spain). This subject has a teaching load of four hours per week and does not count for university entrance exams. The group included 17 females and 13 males. Age ranged between 16 and 17 years old (16 years on average).

\subsection{Study Design}

A mixed investigation was designed to answer the questions raised (Burke \& Onwuegbuzie, 2004). A quasi-experimental longitudinal study (pre/post-test) was carried out in order to evaluate student knowledge before and after the implementation of the educational proposal (Arnau, 1995). Qualitative research techniques were also used to evaluate the enquiry work carried out by the students (Denzin \& Lincoln, 2000). The students' perceptions of the methodology followed was also assessed through an open question in which students were asked to identify the positive and negative aspects of the pedagogical model used.

\subsection{Description of the Classroom Experience}

The classroom experience undertaken in this study is part of a proposal designed to allow Baccalaureate students to work autonomously on content related to human pathophysiology. Specifically, an educational experience is presented based on the flipped classroom methodology and inquiry-based learning related to the anatomy and pathophysiology of the digestive system. This study was carried out during the second term of the 2017/2018 academic year over twelve sessions ( 3 sessions/week) of 50 minutes each (Figure 1).

\begin{tabular}{|c|c|c|c|c|c|c|c|c|}
\hline & Session 1 & Session 2 & Session 3 & Sessions 4, 5, 6 & Sessions $7 \& 8$ & Sessions $9 \& 10$ & Session 11 & Session 12 \\
\hline 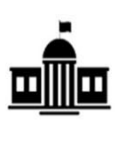 & $\begin{array}{l}\text { Explanation of the } \\
\text { flipped classroom } \\
\text { methodology and } \\
\text { inquiry-based } \\
\text { learning }\end{array}$ & $\begin{array}{l}\text { Explanation } \\
\text { of the tasks } \\
\text { to be } \\
\text { performed }\end{array}$ & $\begin{array}{c}\text { Task } 1 \\
\text { Pre-test } \\
\text { questionnaire }\end{array}$ & $\begin{array}{c}\text { Task } 5 \\
\text { Flipped } \\
\text { activities }\end{array}$ & $\begin{array}{c}\text { Task } 6 \\
\text { inquiry work }\end{array}$ & \begin{tabular}{|c} 
Task 7 \\
Presentation of \\
works and \\
discussion
\end{tabular} & $\begin{array}{c}\text { Task } 8 \\
\text { Exam } \\
\text { (test type) }\end{array}$ & $\begin{array}{c}\text { Task } 9 \\
\text { Evolution } \\
\text { (post-test) and } \\
\text { opinion } \\
\text { questionnaire }\end{array}$ \\
\hline 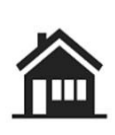 & & & \multicolumn{2}{|c|}{$\begin{array}{c}\text { Task } 2 \\
\text { Download and view all } \\
\text { material that students } \\
\text { need to study before class }\end{array}$} & $\begin{array}{c}\text { Task } 3 \\
\text { Study } \\
\text { Verification } \\
\text { Questionnaire }\end{array}$ & $\begin{array}{c}\text { Task } 4 \\
\text { Student-teacher } \\
\text { interaction }\end{array}$ & & \\
\hline
\end{tabular}

Figure 1. Design of the classroom experience implemented with students of 1st Baccalaureate on anatomy and pathophysiology of the digestive system 
The first session was used to explain the basics of the flipped classroom and inquiry methodologies, using approximately $50 \%$ of the session time for each topic. The first part of session was mostly used to explain the flipped classroom methodology to students. Access to the digital platform of the educational centre where the teacher would place all the necessary syllabus was explained. The handling of Google Forms and Plickers tools was also taught in order for students to answer the questionnaires and exams. The second part of the first session was used to explain in detail the inquiry as a working method. The inquiry work that should be carried out was also thoroughly explained, carefully detailing each of the stages and steps. In the second session, the students were informed of the tasks they would have to perform.

In the third session, students completed the pre-test questionnaire related to digestive anatomy and pathophysiology (Annex 1) using the Google Forms application. In the fourth, fifth and sixth sessions, the students consumed in-class time working on various active-learning activities such as simple experiments, collaborative works, case studies and practical exercises (Table 1). The students had a channel to inform their teacher, using the school's digital platform, of any difficulties or doubts that they had experienced before their arrival in the classroom, allowing the teacher to better plan their interventions to help the students to overcome those difficulties using the just-in-time teaching technique (Novak et al., 1999). This channel was widely used by the students due to the great amount of doubts that arose and for this reason, the flipped design also included short in-class lectures ( $\sim 5$ minutes) to focus on more difficult concepts.

In the seventh and eighth sessions, the students undertook cooperative inquiry work. The 30 participating students were randomly divided into six groups of five students each, and each group was randomly assigned a topic on which they should carry out a research project (Table 2). The next two sessions ( 9 and 10) were used for oral presentations of the inquiry work carried out, and opening a small debate at the end so that the rest of the groups ask questions. The eleventh session was dedicated to the knowledge test, consisting of 20 test questions, on the http://www.plickers.com platform.

\begin{tabular}{|l|l|}
\hline \multicolumn{1}{|c|}{ Activity } & \multicolumn{1}{c|}{ Description } \\
\hline Worksheets & $\begin{array}{l}\text { Students complete handouts identifying digestive organs and matching them to their } \\
\text { functions. }\end{array}$ \\
\hline Clicker questions & $\begin{array}{l}\text { Students were presented with a clicker question with multiple-choice responses. Students } \\
\text { were encouraged to discuss ideas with their nearest peers and vote on the best response. For } \\
\text { example, students were asked to predict which of the organs (from a list) are present in the } \\
\text { digestive system and which are not. }\end{array}$ \\
\hline Online animations & $\begin{array}{l}\text { Students watched various online digestive system animations (e.g., } \\
\text { https://www.youtubecom/watch?v=4dG2PYD94es) and answered questions about } \\
\text { mechanical and chemical digestion, peristalsis, gastric secretion, absorption, excretion, etc. }\end{array}$ \\
\hline Group experiments & $\begin{array}{l}\text { Students, distributed in groups of no more than 5 individuals, were asked to make a model } \\
\text { of one of the anatomical structures that make up the digestive system. For example, a group } \\
\text { made a model of the liver using brown clay to create the lobes, blue modeling foam to create } \\
\text { the inferior vena cava and the portal vein, red foam to make the proper hepatic artery and } \\
\text { green foam to make the gallbladder. Each group was asked to explain the role played by the } \\
\text { anatomical structure they had chosen within the digestive system. }\end{array}$ \\
\hline Practical exercise & $\begin{array}{l}\text { Students observe the digestion process using paper cups, orange juice and a pair of tights. } \\
\text { This simple experiment enables students to visualise the process of digestion in an engaging, } \\
\text { practical way. }\end{array}$ \\
\hline $\begin{array}{l}\text { Biomathematical } \\
\text { problems }\end{array}$ & $\begin{array}{l}\text { Students, for example, were asked to describe the digestion and metabolism of } \\
\text { carbohydrates, fats and proteins. Students were then asked to draw a schematic diagram of } \\
\text { how these macromolecules are broken down and absorbed into the body. }\end{array}$ \\
\hline
\end{tabular}

Table 1. Examples of in-class activities used in the flipped design 


\begin{tabular}{|c|l|}
\hline Group & \multicolumn{1}{c|}{ Topic } \\
\hline 1 & The oral cavity: Oral digestion \\
\hline 2 & Swallowing: Voluntary and involuntary phases \\
\hline 3 & The stomach: Gastric digestion \\
\hline 4 & The small intestine: intestinal digestion \\
\hline 5 & The large intestine: bacteria reservoir \\
\hline 6 & Digestive diseases \\
\hline
\end{tabular}

Table 2. Themes of the baccalaureate inquiry works

In the last session, students had to take the evolution test, or post-test, using the Google Forms tool, which had the same questions as the questionnaire (or pre-test) at the beginning of the proposal (Annex 1). The task was carried out several days after the knowledge test in order to assess those concepts that become persistent ideas. Twenty-three complete pairs of questionnaires (pre and post-test) were obtained, since there were seven students who did not complete either of the two questionnaires. Part of this session was also set aside for students to express their opinions about the methodology followed $(\mathrm{n}=26)$.

\subsection{Information collection and data analysis instruments}

The instruments used to obtain the information were:

1. A questionnaire on the anatomy and pathophysiology of the digestive system based on data obtained from interviews with other teachers, class observations and exams from previous years. The questionnaire was submitted for validation, first, to test and review by two professors of the Department of Didactics of Experimental Sciences of the University of Valladolid and by two teachers at the school where the study was developed (a semi-private school of Valladolid). A first version of the questionnaire was provided to 10 students on a higher course (2nd Baccalaureate). The questionnaire was again reviewed by the professors involved in the study. The final questionnaire consisted of six open questions and four closed multiple-choice questions (Annex 1). In order to compare the results obtained by each student in the pre-test against those obtained in the post-test, the symmetry hypothesis was confirmed, applying McNemar's contrast from the contingency table, using the Statgraphics Centurion XVII program.

2. An open question where students were asked to indicate the positive and negative aspects they considered most important about the methodology used ("Please, could you indicate the highlights, for and against, related to the pedagogical model used?"). For each category (positive or negative), a descriptive analysis was applied, using as descriptive statistics the frequency and percentages of each item/aspect.

The inquiry work carried out by the students was evaluated using the New Practical Test Assessment Inventory (NPTAI) and Inquiry Competence Levels (ICL) instruments designed by Ferrés et al. (2015), and the adaptation that Rosa (2019) later introduced in the "Hypothesis formulation" category. These instruments value the inquiry competence of students, which is understood as the ability of students to understand and apply research. The NPTAI instrument consists of 7 categories with their respective headings, and addresses different aspects of the understanding of enquiry processes, such as the identification of inquiry problems, the ability to formulate hypotheses, the identification of the variables of an experimental design, the competence to analyse data and draw conclusions, etc. Within each category, the instrument allows a numerical rating of 0 to 2 or 0 to 4 to obtain a quantitative assessment from the evaluation of qualitative data, such as those obtained from the research reports. To establish the ICL, the NPTAI must first be applied to the research work and five categories are differentiated depending on the value obtained: unscientific, for the NPTAI value interval between 0 and 5; prescientific, between 6 and 7; incipient inquirer, for 8 to 10; insecure inquirer, for 11 to 13; and inquirer, when the values obtained in the NPTAI are greater than 14 . 


\section{Results and Discussion}

\subsection{High School Learning Outcomes After the Implementation of the Didactic Proposal}

Before the implementation of the educational proposal, the students had a fairly shallow knowledge of digestive pathophysiology. As can be seen in Figure 2, most students answered the questions incorrectly in the pre-test. Less than $25 \%$ of students answered 5 of the 10 questions correctly (Questions 2, 6, 7, 8 and 10), and none of the 23 participants answered Questions 6 and 8 correctly. Student knowledge improved significantly after following the proposed learning techniques. The results of the post-test show that the number of students who answered the questions correctly was significantly higher $(\mathrm{p}<0.05)$ than in the pre-test (Figure 2), and no question was answered with more success in the pretest that in the post-test. It is necessary to remember that this test of evolution (post-test) was carried out several days after the exam that the students took, demonstrating that it was not a memory issue but that the students had internalised the concepts raised. Figure 2 also shows that the questions can be grouped into two large blocks according to the degree of success. In the first group, Questions 1 to \# 5 (Annex 1), the results were significantly better $(\mathrm{p}<0.05)$ than in the second block (Questions 6 to \# $10)$, both in the pre-test and in the post-test, probably because these were basic questions. Taking into account that these concepts should have been known by almost the entire group, their response value was markedly increased in the post-test, especially in Question 2, which went from five hits in the initial evaluation to 18 in the final evaluation, and Questions 1, 3 and 5, where improvements close to $40 \%$ were recorded. The questions in the second block (from 6 to 10) were more specific to this year of high school and they were slightly more difficult than those of the first block (Annex 1). Even so, important improvements were registered, such as for Questions 6, 8 and 10 where nine, five and ten students responded correctly, respectively, from the original total or almost total lack of knowledge of the whole group (Figure 2).

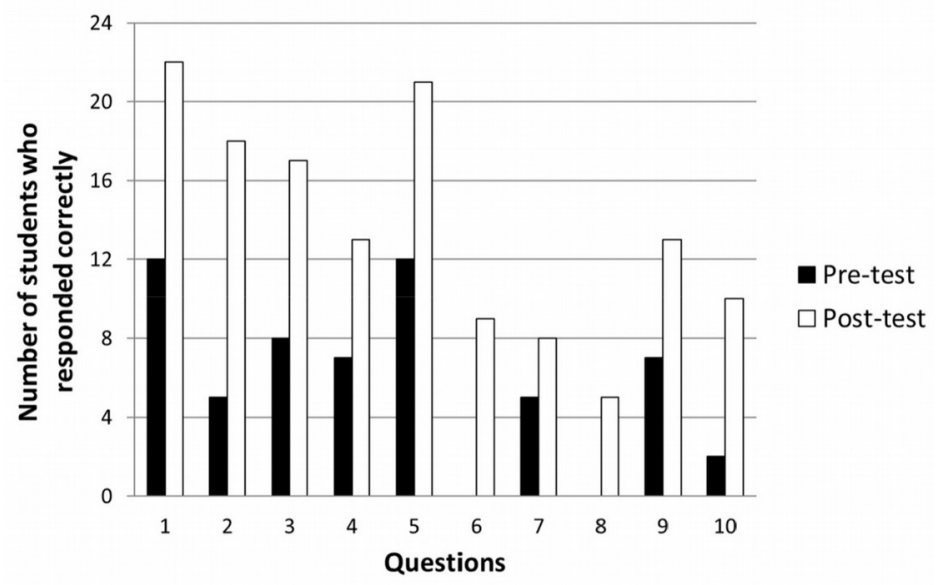

Figure 2. Comparison of the correct answers given by the students in the initial and final evaluation (pre-test vs. post-test)

These learning results show that the implementation of the reverse methodology carried out with this group of students was highly satisfactory. It is necessary to highlight that the objective of this study was not to verify whether this type of methodology contributes to achieving better learning outcomes than traditional instructional methods, an aspect that has been widely addressed in recent years and that seems to have been demonstrated after the last studies published, especially in university contexts (Davies et al., 2013; González-Gómez, Jeong \& Picó, 2017; Herreid \& Schiller, 2013; Jeong, Cañada-Cañada \& González-Gómez, 2018; Knight \& Wood, 2005; Love, Hodge, Grandgenett \& Swift, 2013; Mason, Rutar \& Cook, 2013; Mattis, 2015; Torrecilla, 2018). What we really wanted to assess with this research is whether the inverted methodology can be applied in the Baccalaureate, an educational environment where there are no curricular hours dedicated to personal work and/or at home, unlike in university teaching, in 
which an ECTS credit is 25 hours of work, of which 10 are face-to-face and 15 are study and personal dedication. This curricular difference, together with the substantial change required for students to work with this type of methodology, which required greater daily effort, preparation or study prior to classes, and much more autonomous learning than they may have been accustomed to with traditional teaching models, were probably the biggest handicaps our high school students faced. A negative research result would indicate or suggest that the proposal would not be applied satisfactorily in the field studied. The implementation of the proposal also took place once the course had already begun, which made its development even more difficult. Even so, the results showed that most of the study participants successfully assimilated the topics discussed in the unit, even those that could not simply be memorised in isolation and that required relationship between concepts, processes and, in general, the digestive system as part of the human body.

\subsection{Student Perceptions of Methodology Followed}

One of the characteristics that the students highlighted most positively $(n=23 ;>85 \%)$ in the methodology used was having the syllabus in advance of the classes. This aspect of the inverted model, already cited by other authors (Aljaraideh, 2019; González-Gómez et al., 2017; Jeong et al., 2018; Torío, 2019), allowed students to visualise the content provided by the teacher as often as they wanted, contributing to increasing their conceptual understanding and allowing each student to work at their own pace, better organising their time and preparing classes in a more active way. Other advantages highlighted by our high school students, and which are also reflected in similar studies (Ismail \& Abdulla, 2019; Martín \& Santiago, 2015; Mason et al., 2013; Moraros, Islam, Yu, Banow \& Schindelka, 2015; Roach, 2014; Sánchez-Rivas, Sánchez-Rodríguez \& Ruiz-Palmero, 2019), were the greatest dedication of time in the classroom to carry out inquiry activities or practical research $(n=20 ; 76.9 \%)$, the greater ability of the teacher to take into account the strengths, weaknesses and interests of each of the students $(n=17$; $65.4 \%)$, that interactions with the teacher and with their classmates had been more frequent and positive $(\mathrm{n}=16 ; 61.5 \%)$ and an increase in the student's motivation towards the subject and study $(\mathrm{n}=14 ; 53.8 \%)$.

The negative aspects pointed out by the students included the greater daily effort that this type of methodology requires, both in preparation for the classes and in the activities to be carried out at home $(n=22 ; 84.6 \%)$, and the greater degree of autonomy that this type of learning requires $(n=16 ; 61.5 \%)$. This negative feedback may be because this new model requires more time and energy preparing for class and much more autonomous learning than perhaps they are accustomed to in traditional teaching models. These results suggest that flipped classroom approach can enhance a student's sense of active participation, but at the same time increasing their workload, negatively impacting their satisfaction (Tang, Chen, Zhu, Zuo, Zhong, Wang et al., 2017). A small group of students (15-20\%) demonstrated low motivation to work with this type of methodologies, either because the activities proposed were not to their liking or because the teachers responsible for implementing this model were not able to convey the advantages of this new educational environment. Similar studies (Strayer, 2012) indicate that the effectiveness of this model, where the student owns their own learning, varies depending on the subject in which it was used and that the degree of dissatisfaction increases when students have no interest, since they feel frustrated by the dynamics of the classroom and the way in which their orientation is structured with the flipped classroom. As noted above, this is the first time inverted instruction has been used with our students, and therefore, it is not surprising that they show a certain reluctance to change. The inverted learning model, like any other type of non-traditional learning, requires a substantial change in the mentality and study habits of students, things that must be carried out gradually so that students can adapt to them and not perceive it as excessive effort.

\subsection{Evaluation of The Inquiry Works Carried Out by The High School Students}

The results of the evaluation of the inquiry carried out by the students are presented in Table 3, using the NPTAI and NCI instruments (Ferrés et al., 2015; Rosa, 2019). 
As can be seen in this table, three of the groups (Groups 2, 5 and 6) were rated as "Unscientific", with an NPTAI score below 5 . These groups described the assigned topic well, but they did not include questions to be investigated, or associated hypotheses, despite the attempts of the teacher to highlight the importance of these stages in an inquiry project. This meant that the variables to be studied could not be defined and, so an investigation as such could not be carried out.

\begin{tabular}{|l|c|c|c|c|c|c|}
\hline \multirow{2}{*}{} & \multicolumn{7}{|c|}{ Group } & G6 \\
\cline { 2 - 7 } & G1 & G2 & G3 & G4 & G5 & G6 \\
\hline Identification of inquiry problems (0-2) & 2 & 0 & 1 & 1 & 0 & 0 \\
\hline Hypothesis formulation (0-4) & 4 & 0 & 2 & 2 & 0 & 0 \\
\hline Variable identification (0-4) & 3 & 0 & 1 & 1 & 0 & 0 \\
\hline Research planning (0-4) & 3 & 0 & 1 & 1 & 0 & 0 \\
\hline Data collection and processing (0-4) & 4 & 0 & 2 & 1 & 0 & 1 \\
\hline Data analysis and conclusions (0-4) & 4 & 1 & 2 & 2 & 1 & 1 \\
\hline Metareflection (0-2) & 2 & 0 & 1 & 1 & 0 & 0 \\
\hline NPTAI score (0-24) & 22 & 1 & 10 & 9 & 1 & 2 \\
\hline ICL & I & U & II & II & U & U \\
\hline
\end{tabular}

I: Inquirer (NPTAI score: >14); II: Incipient inquirer (NPTAI score: 8-10); U: Unscientific (NPTAI score: 0-5).

Table 3. NPTAI score and Inquiry Competence Level (ICL) obtained by each research group/project

Two other groups (Groups 3 and 4) reached NPTAI values of 10 and 9, respectively, placing themselves in the category of "Incipient Inquirer/s". These students made a detailed description of the assigned anatomical area and searched for a bibliography on the associated pathophysiology, mainly through the "PubMed" database (https://www.ncbi.nlm.nih.gov/pubmed/). The students of these groups designed retrospective cohort studies to try to answer these questions and corroborate the hypotheses formulated, collecting and analysing the latest series of published cases. The lack of specificity in the variables included in the study, as well as certain inaccuracies in the methodological design and in the analysis of the data, caused the scores obtained in these categories to be relatively low.

The remaining group (Group 1) reached the highest level of inquiry competence, with an NPTAI score higher than 14, which is the limit established by Ferrés et al. (2015) to catalogue a student/group of students as "Inquirer/s". This group, like the rest, conducted an exhaustive literature search on the assigned topic, which was saliva, and more specifically, the absence of saliva caused by some pathologies, the aspect that most caught their attention, not only because of the importance that this body fluid has in the oral digestive process but also for the rest of the functions it presents (gustatory, protective, healing, buffering, etc.). Students were able to transform initially proposed declarative questions into researchable questions. This question was rated with the highest score in this category, as it was perfectly formulated, connected variables and allowed a methodological design for answering it.

The next step for the students was to formulate a hypothesis that tried to answer the question posed. Groups 3 and 4 proposed acceptable hypotheses, but group 1 stood out for the proposed hypothesis. The members of this group decided to propose the following hypothesis: Quantitative measurements of salivary flow are the only tests necessary to achieve an accurate diagnosis of xerostomia. This hypothesis fits perfectly with the research problem and for this reason, it was assessed with the highest score, considering the criteria established in the adaptation of the NPTAI by Rosa (2019). Next, the students planned the research to be carried out, identifying all the variables they considered necessary to do so. It is necessary to highlight at this point that, it was obviously not possible to propose a prospective study with real patients, the students had to design a retrospective observational study, analysing the etiopathogenesis of xerostomia, and all the tests and markers used to make its diagnosis. These two categories (variable identification and research planning) were rated with a very good score when applying the NPTAI instrument, however, the lack of 
certain variables to include in the study and small inaccuracies in the methodological design prevented them from reaching the highest scores.

The collection and processing of data was probably the task that generated the most problems for our students, not only because of their lack of training, but also because of the difficulty involved in carrying out a retrospective study of cases and controls such as that proposed by this group. This type of study requires handling huge amounts of data and having extensive experience to process all available information. The same is true of the analysis of the data obtained and the elaboration of conclusions, which are very complicated tasks even for researchers with consolidated trajectories. An example was the search for information the students carried out through the "ClinicalTrials.gov" database (https://clinicaltrials.gov). Even so, the students, thanks to their good predisposition and the guidance received from their teacher, were able to complete these tasks satisfactorily, obtaining the highest scores when applying the NPTAI instrument (group 1 and, to a lesser extent, groups 3 and 4, Table 3).

The last section of the work was the "Metareflection", a stage where students explain the characteristics of a process of scientific inquiry. Groups 3 and 4 obtained an acceptable score but group 1 obtained the best result (Table 3). As we have said before, the students in this group showed great interest in learning, and what is more important, they followed the guidelines of their teacher in the aspects that presented more difficulties, which allowed them to deepen their knowledge in each of the stages of the work. This is why they had few problems carrying out a detailed description of the inquiry process, obtaining the highest rating when applying the NPTAI instrument.

\section{Conclusions and Educational Implications}

This article presented an educational experience with high school students based on the flipped classroom methodology and inquiry-based learning on aspects related to the anatomy and pathophysiology of the digestive system in which it tried to assess:

\subsection{Students' Performance}

We were able to verify that the implementation of the inverted methodology carried out with this group of high school students was highly satisfactory. This pedagogical approach is born in the university environment, and its applicability and effectiveness in that context seem more than evident (Abushammala, 2019; Davies et al., 2013; Eldy, Chang, Butai, Basri, Awang, Din et al., 2019; González-Gómez et al., 2017; Herreid \& Schiller, 2013; Jeong et al., 2018; Knight \& Wood, 2005; Love et al., 2013; Mason et al., 2013; Mattis, 2015; Torrecilla, 2018), however, at pre-university educational levels, where there are no hours in the curriculum dedicated to personal work and/or at home, its implementation is more complicated. The reverse learning model, like any other type of non-traditional learning, requires a substantial change in the mentality of the students and a radical change in class dynamics, aspects that must be carried out gradually so that students can adapt to them and become protagonists of their own learning process. Ideally, annual planning will be undertaken at the beginning of the course, detailing and explaining what it is, and how it will work, so that students perceive the benefits of this new educational environment. This is probably the biggest limitation in this, since the changes introduced took place after the course had started, and after having worked with another type of methodology. Even so, our results show that the experience was clearly positive, since there was not only a significant improvement in student learning but also greater autonomy for students to work with the content, prepare for classes and actively participate in the tasks or practical activities that take place in the classroom. Another conclusion that we were able to draw from this research, and that is essential in order for this type of methodology to be satisfactorily implemented in high school classrooms, is the imperative need for both students and teachers to be well predisposed to this change in roles, since this is only in this way is it possible to achieve an adequate transition to the desired learning model. 


\subsection{Students' Perceptions}

Finally, and in the light of the opinions expressed by the students about the pedagogical model used, it is evident that most of the students perceived following an active and dynamic methodology, being able to access the contents in an easy way, and quickly, having some autonomy to set their own learning pace, carrying out research activities during classes, collaborating with their peers in different learning experiences, and the involvement and closeness of teachers as beneficial to their learning.

\subsection{Students' Inquiry Competence Level}

We also observed that the level of inquiry competence reached by high school students when carrying out their research work was relatively low, despite it being carried out within the framework of the "flipped classroom" methodology. With the exception of one group, which reached the highest possible level of inquiry competence, the rest had serious problems when carrying out such work. These difficulties began with the formulation of the inquiry questions, since in most cases they were limited to information questions that did not give rise to any type of investigation, and that could be resolved based solely on content. This erroneous approach caused a chain reaction to the rest of the processes or skills related to the investigation (hypothesis formulation, identification of variables, research planning, data collection, etc.), which resulted in purely descriptive works that did not contemplate any type of research activity. This was the first time that our students undertook work of this type, so it is not surprising that the results were not as positive as expected. Based on these results and as a starting point for students to carry out a true investigation, we consider it essential that students are trained in the development of inquiry thinking and the research work is done in a guided way. Another aspect that we consider important is to propose a greater number of activities to improve the ability to formulate inquiry questions, an essential condition for the development of true research. Similarly, we also believe it is necessary to devote more time and effort to helping students to understand the importance of each of the stages that make up the inquiry process. In this sense, the improvement of the flipped classroom model can provide the appropriate methodological aspects. We also consider it essential that students begin to develop this competence in the initial stages of their education and, always gradually. Open and autonomous research should not be proposed to students until they have sufficient research experience at the lower levels of the educational stage.

\section{Declaration of Conflicting Interests}

The authors declared no potential conflicts of interest with respect to the research, authorship, and/or publication of this article.

\section{Funding}

The authors received no financial support for the research, authorship, and/or publication of this article.

\section{References}

Abushammala, M.F.M. (2019). The effect of using flipped teaching in project management class for undergraduate students. Journal of Technology and Science Education, 9(1), 41-50. https://doi.org/10.3926/jotse.539

Alfieri, L., Brooks, P.J., Aldrich, N.J., \& Tenenbaum, H.R. (2011). Does discovery-based instruction enhance learning? Journal of Educational Psychology, 103, 1-18. https://doi.org/10.1037/a0021017

Aljaraideh, Y. (2019). Students' perception of flipped classroom: A case study for private universities in Jordan. Journal of Technology and Science Education, 9(3), 368-377. https://doi.org/10.3926/jotse.648

Arnau, J. (1995). Metodologies quantitatives en la investigació psicológica [Quantitative methodologies in psychological research]. In Arnau, J. (Ed.), Mètodes, dissenys i tècniques en investigació psicològica (Methods, designs and techniques in psychological research). Universitat Oberta de Catalunya. 
Bergmann, J., \& Sams, A. (2012). Flip your classroom: Reach every student in every class every day. International Society for Technology in Education.

Bevins, S., \& Price, G. (2016). Reconceptualising inquiry in science education. International Journal of Science Education, 38(1), 17-29. https://doi.org/10.1080/09500693.2015.1124300

Burke, R., \& Onwuegbuzie, A. (2004). Mixed methods research: A research paradigm whose time has come. Educational Researcher, 33(7), 14-26. https://doi.org/10.3102/0013189X033007014

Caamaño, A. (2012). ¿Cómo introducir la indagación en el aula? (How to introduce the inquiry into the classroom?). Alambique. Didáctica de Las Ciencias, 70, 83-91.

Couso, D., Jiménez, M.P., López-Ruiz, J., Mans, C., Rodríguez, C., Rodríguez, J.M., et al. (2011). Informe ENCIENDE: Enseñanza de las Ciencias en la Didáctica escolar para edades tempranas en España (ENCIENDE Report: Science teaching in school didactics for early ages in Spain). Rubes Editorial.

Crujeiras, B., \& Jiménez, M.P. (2015). Desafíos planteados por las actividades abiertas de indagación en el laboratorio: articulación de conocimientos teóricos y prácticos en las prácticas científicas (Challenges posed by open inquiry tasks in the laboratory: articulation of theoretical and practical knowledge in scientific practices). Enseñanza de las Ciencias, 33(1), 63-84. https://doi.org/10.5565/rev/ensciencias.1469

Cruz-Guzmán, M., García-Carmona, A., \& Criado, A.M. (2017). An analysis of the questions proposed by elementary pre-service teachers when designing experimental activities as inquiry. International Journal of Science Education, 39(13), 1755-1774. https://doi.org/10.1080/09500693.2017.1351649

Davies, R.S., Dean, D.L., \& Ball, N. (2013). Flipping the classroom and instructional technology integration in a college-level information systems spreadsheet course. Educational Technology Research and Development, 61(4), 563-580. https://doi.org/10.1007/s11423-013-9305-6

Dávila, M.A., Borrachero, A.B., Cañada, F., Martínez, G., \& Sánchez-Martín, J. (2015). Evolución de las emociones que experimentan los estudiantes del grado de maestro en educación primaria, en didáctica de la materia y la energía [Evolution of the emotions experienced by prospective Primary teachers, focused on Didactics of Matter and Energy]. Revista Eureka sobre Enseñanza y Divulgación de las Ciencias, 12(3), 550-564. https://doi.org/10.25267/Rev_Eureka_ensen_divulg_cienc.2015.v12.i3.12

D’Costa, A., \& Schlueter, M. (2013). Scaffolded instruction improves student understanding of the scientific method and experimental design. The American Biology Teacher, 75, 18-28.

https://doi.org/10.1525/abt.2013.75.1.6

Denzin, N.K., \& Lincoln, Y.S. (2000). The discipline and practice of qualitative research. In Denzin, N.K., \& Lincoln, Y.S. (Eds.), Handbook of Qualitative Research (1-28). Sage Publications.

Eldy, E.F., Chang, J.H.W., Butai, S.N., Basri, N.F., Awang, H., Din, W.A., et al. (2019). Inverted classroom improves pre-university students understanding on basic topic of physics: The preliminary study. Journal of Technology and Science Education, 9(3), 420-427. https://doi.org/10.3926/jotse.599

Fay, E., Grove, N., Towns, M.H., \& Bretz, S. L. (2007). A rubric to characterize inquiry in the undergraduate chemistry laboratory. Chemistry Education Research and Practice, 8(2), 212-219. https://doi.org/10.1039/B6RP90031C

Fernández-López, L. (2011). Los proyectos de investigación del alumnado y las competencias básicas y científicas (Student research projects and basic and scientific skills). In Jiménez Aleixandre, M.P. (Ed.) and Fernández-López, L. (Coord.), Cuaderno de Indagación en el Aula y Competencia Cientifica (Notebook of Inquiry in the Classroom and Scientific Competence) (17- 31). Ministerio de Educación. 
Ferrés, C., Marbà, A., \& Sanmartí, N. (2015). Trabajos de indagación de los alumnos: instrumentos de evaluación e identificación de dificultades (Students' inquiry works: assessment tools and identification of difficulties). Revista Eureka sobre Enseñanza y Divulgación de las Ciencias, 12(1), 22-37.

https://doi.org/10.25267/Rev_Eureka_ensen_divulg_cienc.2015.v12.11.03

Ferrés-Gurt, C. (2017). El reto de plantear preguntas científicas investigables (The challenge for proposing inquiry questions). Revista Eureka sobre Enseñanza y Divulgación de las Ciencias, 14(2), 410-426. https://doi.org/10.25267/Rev_Eureka_ensen_divulg_cienc.2017.v14.i2.09

Furman, M., Barreto, M. del C., \& Sanmartí, N. (2013). El proceso de aprender a plantear preguntas investigables (The process of learning to ask questionable questions). Educació Quimica, 14, 1-16.

Furtak, E.M., Seidel, T., Iverson, H., \& Briggs, D.C. (2012). Experimental and quasi-experimental studies of inquiry-based science teaching. Review of Educational Research, 82(3), 300-329.

https://doi.org/10.3102/0034654312457206

González-Gómez, D., Jeong, J.S., Airado-Rodríguez, D., \& Cañada-Cañada, F. (2016). Performance and perception in the flipped learning model: An initial approach to evaluate the effectiveness of a new teaching methodology in a general science classroom. Journal of Science Education and Technology, 25, 450-459. https://doi.org/10.1007/s10956-016-9605-9

González-Gómez, D., Jeong, J.S., \& Picó, A.G. (2017). La enseñanza de contenidos científicos a través de un modelo "Flipped": Propuesta de instrucción para estudiantes del Grado de Educación Primaria (Teaching science contents through a "Flipped" model: An instruction example for Primary Education bachelor students). Enseñanza de las ciencias: revista de investigación y experiencias didácticas, 35(2), 71-87. https://doi.org/10.5565/rev/ensciencias.2233

González, L., \& Crujeiras, B. (2016). Aprendizaje de las reacciones químicas a través de actividades de indagación en el laboratorio sobre cuestiones de la vida cotidiana (Learning chemical reactions through inquiry-based laboratory tasks about everyday life issues). Enseñanza de las Ciencias, 34(3), 143-160. https://doi.org/10.5565/rev/ensciencias.2018

Gopalan, C. (2019). Effect of flipped teaching on student performance and perceptions in an introductory physiology course. Advances in Physiology Education, 43, 28-33. https://doi.org/10.1152/advan.00051.2018

Herreid, C.F., \& Schiller, N.A. (2013). Case studies and the flipped classroom. Journal of College Science Teaching, 42(5), 62-66.

Ismail, S.S., \& Abdulla, S.A. (2019). Virtual flipped classroom: new teaching model to grant the learners knowledge and motivation. Journal of Technology and Science Education, 9(2), 168-183. https://doi.org/10.3926/jotse.478

Jeong, J.S., González-Gómez, D., \& Cañada-Cañada, F. (2016). Students' perceptions and emotions toward learning in a flipped general science classroom. Journal of Science Education and Technology, 25, 747-758. https://doi.org/10.1007/s10956-016-9630-8

Jeong, J.S., Cañada-Cañada, F., \& González-Gómez, D. (2018). The study of flipped-classroom for pre-service science teachers. Education Sciences, 8, 163. https://doi.org/10.3390/educsci8040163

Jeong, J.S., González-Gómez, D., Cañada-Cañada, F., Gallego-Picó, A., \& Bravo, J.C. (2019). Effects of active learning methodologies on the students' emotions, self-efficacy beliefs and learning outcomes in a science distance learning course. Journal of Technology and Science Education, 9(2), 217-227.

https://doi.org/10.3926/jotse.530

Knight, J.K., \& Wood, W.B. (2005). Teaching more by lecturing less. Cell Biology Education, 4, 298-310. https://doi.org/10.1187/05-06-0082 
Lazonder, A.W., \& Harmsen, R. (2016). Meta-analysis of inquiry-based learning effects of guidance. Review of Educational Research, 20(10), 1-38.

Lederman, N.G., Lederman, J.S., \& Antink, A. (2013). Nature of science and scientific inquiry as contexts for learning of science and achievement of scientific literacy. International Journal of Education in Mathematics, Science and Technology, 1(3), 138- 147.

Long, T., Logan, J., \& Waugh, M. (2016). Students' perceptions of the value of using videos as a pre-class learning experience in the flipped classroom. TechTrends, 60, 245-252. https://doi.org/10.1007/s11528-016$0045-4$

Love, B., Hodge, A., Grandgenett, N., \& Swift, A.W. (2013). Student learning and perceptions in a flipped linear algebra course. International Journal of Mathematical Education in Science and Technology, 45(3), 317-324. https://doi.org/10.1080/0020739X.2013.822582

Martín, D., \& Santiago R. (2015). ¿Es el flipped classroom un Modelo Pedagógico eficaz?: Un estudio sobre la percepción de estudiantes de primaria, ESO y bachillerato (Is the flipped classroom an effective Pedagogical Model? A study of the perception of elementary, ESO and high school students). Comunicación y pedagogia: Nuevas tecnologias y recursos didácticos, 285, 29-35.

Martínez-Chico, M., Jiménez-Liso, M.R. \& López-Gay, R. (2014). La indagación en las propuestas de formación inicial de maestros: análisis de entrevistas a formadores de Didáctica de las Ciencias Experimentales (Model-based inquiry for pre-service primary teacher training: science teacher educators' interview analysis). Enseñanza de las Ciencias, 32(3), 591-608. https://doi.org/10.5565/rev/ensciencias.1376

Mason, G.S., Rutar, T.S., \& Cook, K.E. (2013). Comparing the effectiveness of an inverted classroom to a traditional classroom in an upper-division engineering course. IEEE Transactions on Education, 56(4), 430-435. https://doi.org/10.1109/TE.2013.2249066

Mattis, K.V. (2015). Flipped classroom versus traditional textbook instruction: Assessing accuracy and mental effort at different levels of mathematical complexity. Technology, Knowledge and Learning, 20(2), 231-248. https:// doi.org/10.1007/s10758-014-9238-0

Minner, D., Levy, A., \& Century, J. (2010). Inquiry-based science instruction-What is it and does it matter? Results from a research synthesis years 1984 to 2002. Journal of Research in Science Teaching, 47, 474-496. https://doi.org/10.1002/tea.20347

Moraros, J., Islam, A., Yu, S., Banow, R., \& Schindelka, B. (2015). Flipping for success: Evaluating the effectiveness of a novel teaching approach in a graduate level setting. BMC Medical Education, 15(27), 1-10. https://doi.org/10.1186/s12909-015-0317-2

National Research Council (NRC) (2012). A framework, for K12 Science Education: practices, crosscutting concepts and core ideas. National Academy Press.

Novak, G., Gavrin, A., Christian, W., \& Patterson, E. (1999). Just-in-time teaching: Blending active learning with web technology. Prentice-Hall. https://doi.org/10.1119/1.19159

O'Flaherty, J., \& Phillips, C. (2015). The use of flipped classrooms in higher education: A scoping review. Internet and Higher Education, 25, 85-95. https://doi.org/10.1016/j.iheduc.2015.02.002

Ofsted (2011). Successful science: An evaluation of science education in England 2007 - 2010. Ofsted.

Oliveras, B., Márquez, C., \& Sanmartí, N. (2012). Aprender a leer críticamente (Learn to read critically). Alambique, 70, 37-45.

Osborne, J. (2011). Science teaching methods: A rationale for practices. School Science Review, 93(343) 93-103. 
Pimvichai, J., Yuenyong, C., \& Buaraphan, K. (2019). Development of grade 10 students' scientific argumentation through the science-technology-society learning unit on work and energy. Journal of Technology and Science Education, 9(3), 428-441. https://doi.org/10.3926/jotse.527

Prieto, A. (2017). Flipped Learning: Aplicar el modelo de Aprendizaje Inverso (Flipped learning: Applying the inverted learning model). Editorial Narcea.

Roach, T. (2014). Student perceptions toward flipped learning: New methods to increase interaction and active learning in economics. International Review of Economics Education, 17, 74-84.

https://doi.org/10.1016/j.iree.2014.08.003

Romero-García, C., Buzón-García, O., \& Touron, J. (2018). The flipped learning model in online education for secondary teachers. Journal of Technology and Science Education, 9(2), 109-121.

https://doi.org/10.3926/jotse.435

Rosa, S.M. (2019). Proyectos de investigación en los estudios universitarios: progreso de la observación a la indagación (Research projects on undergraduate courses: From observation to inquiry). Enseñanza de las ciencias, 37(1), 195-211. https://doi.org/10.5565/rev/ensciencias.2607

Rusmansyah, R., Yuanita, L., Ibrahim, M., Isnawati, I., \& Prahani, B.K. (2019). Innovative chemistry learning model: Improving the critical thinking skill and self-efficacy of pre-service chemistry teachers. Journal of Technology and Science Education, 9(1), 59-76. https://doi.org/10.3926/jotse.555

Sánchez-Rivas, E., Sánchez-Rodríguez, J., \& Ruiz-Palmero, J. (2019). Percepción del alumnado universitario respecto al modelo pedagógico de clase invertida (Perception of university students regarding the inverted class pedagogical model). Magis, Revista Internacional de Investigación en Educación 11(23), 151-168. https://doi.org/10.11144/Javeriana.m11-23.paur

Sanmartí, N., \& Oliveras, B. (2011). Leer críticamente las ideas y pruebas científicas que aportan artículos periodísticos (Read critically the ideas and scientific evidence provided by newspaper articles). In Jiménez Aleixandre, M.P. (Ed.) and Fernández-López, L. (Coord.), Cuaderno de Indagación en el aula y Competencia Cientifica (Notebook of inquiry in the classroom and Scientific Competence) (54-77). Ministerio de Educación.

Sshana, Z.J., \& Abulibdeh, E.S. (2020). Science practical work and its impact on students' science achievement. Journal of Technology and Science Education, 10(2), 199-215. https://doi.org/10.3926/jotse.888

Strayer, J. (2012). How learning in an inverted classroom influences cooperation, innovation and task orientation. Learning Environments Research, 15(2), 171-193. https://doi.org/10.1007/s10984-012-9108-4

Tamir, P., \& García, M. (1992). Características de los ejercicios de prácticas de laboratorio incluidos en los libros de texto de ciencias utilizados en Cataluña (Characteristics of the laboratory practice exercises included in the science textbooks used in Catalonia). Enseñanza de Las Ciencias, 10(1), 3-12.

Tang, F., Chen, C., Zhu, Y., Zuo, C., Zhong, Y., Wang, N., et al. (2017). Comparison between flipped classroom and lecture-based classroom in ophthalmology clerkship. Medical Education Online, 22(1), 1395679. https://doi.org/10.1080/10872981.2017.1395679

Torío, H. (2019). Teaching as coaching: experiences with a video-based flipped classroom combined with project-based approach in technology and physics higher education. Journal of Technology and Science Education, 9(3), 404-419. https://doi.org/10.3926/jotse.554

Torrecilla, S. (2018). Flipped classroom: Un modelo pedagógico eficaz en el aprendizaje de Science (An effective pedagogical model in the learning of science). Revista Iberoamericana de Educación, 76(1), 9-22. https://doi.org/10.35362/rie7612969 
Tourón, J., \& Santiago, R. (2015). El modelo Flipped Learning y el desarrollo del talento en la escuela (The Flipped Learning model and the development of talent in school). Revista de Educación, 368, 196-231.

Ucan, S., \& Webb, M. (2015). Social regulation of learning during collaborative inquiry learning in science: How does it emerge and what are its functions? International Journal of Science Education, 37(15), 2503-2532. https://doi.org/10.1080/09500693.2015.1083634

Vílchez, J.M., \& Bravo, B. (2015). Percepción del profesorado de ciencias de educación primaria en formación acerca de las etapas y acciones necesarias para realizar una indagación escolar (Perceptions of pre-service science teachers in primary education about the steps and actions needed to carry out a school inquiry). Enseñanza de las Ciencias, 33(1), 185-202. https://doi.org/10.5565/rev/ensciencias.1529

\title{
Annex 1. Questions Asked in the Questionnaire of Previous Ideas (Pre-Test) and Evolution Test (Post-Test)
}

1. Please indicate which organ systems of the human body are involved in the nutrition function (you can point out several answers)

2. From a histological point of view, indicate which layers form the wall of the digestive tract (you can point out several answers)

3. Could you define what the mesentery is in a few words?

4. Could you briefly describe the parts of a tooth?

5. Could you briefly explain why we don't drown when we swallow?

6. Aspirin prevents the stomach from secreting mucin. Why is its continuous use counterproductive?

7. Intestinal digestion is carried out by three complementary digestive juices. One of them is the pancreatic juice secreted by the pancreas. Could you point out the main enzymes it contains? (You can give several answers)

8. Probiotics are foods that contain live microorganisms which, given in adequate amounts, confer a health benefit on the one who takes them. Why is its consumption beneficial?

9. Could you briefly define what the intestinal haustra are?

10. Hepatitis is an inflammatory disease that affects the liver. Could you indicate how each of its types is transmitted? (You can give several answers)

\author{
Published by OmniaScience (www.omniascience.com) \\ Journal of Technology and Science Education, 2021 (www.jotse.org)
}

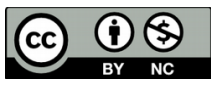

Article's contents are provided on an Attribution-Non Commercial 4.0 Creative commons International License. Readers are allowed to copy, distribute and communicate article's contents, provided the author's and JOTSE journal's names are included. It must not be used for commercial purposes. To see the complete licence contents, please visit https://creativecommons.org/licenses/by-nc/4.0/. 